\title{
L'offense aux souverains et chefs de gouvernement étrangers par la voie de presse
}

Jean Bart

\section{(2) OpenEdition}

1 Journals

Édition électronique

URL : https://journals.openedition.org/ahrf/1872

DOI : 10.4000/ahrf.1872

ISSN : 1952-403X

Éditeur :

Armand Colin, Société des études robespierristes

Édition imprimée

Date de publication : 1 décembre 2004

Pagination : 186-187

ISSN : 0003-4436

Référence électronique

Jean Bart, "L'offense aux souverains et chefs de gouvernement étrangers par la voie de presse »,

Annales historiques de la Révolution française [En ligne], 338 | octobre-décembre 2004, mis en ligne le 22 mars 2006, consulté le 23 avril 2022. URL : http://journals.openedition.org/ahrf/1872 ; DOI : https:// doi.org/10.4000/ahrf.1872

Ce document a été généré automatiquement le 23 avril 2022.

Tous droits réservés 


\section{L'offense aux souverains et chefs de gouvernement étrangers par la voie de presse}

Jean Bart

\section{RÉFÉRENCE}

Jean-François Marinus, L'offense aux souverains et chefs de gouvernement étrangers par la voie de presse, Bruxelles, Éd. Bruylant - Éditions de l'Université de Bruxelles, coll. de droit international, 2002, 587 p., ISBN : 2-8027-1564-X.

1 Cet ouvrage, issu d'une thèse qui se situe au confluent de la science politique, du droit international et de l'histoire peut intéresser les lecteurs de notre revue car son champ chronologique s'étend de la fin de l'Ancien Régime à nos jours et son domaine géographique dépasse largement les limites de la Belgique. D'ailleurs les provinces qui ont formé celle-ci à partir de 1830, n'ont-elles pas été réunies à la France de l'an IV à la chute de Napoléon? Aussi la législation révolutionnaire, puis la politique consulaire et impériale en matière de presse sont-elles abordées par l'auteur en quelques pages (61-68). Sont analysées tour à tour la liberté caractéristique des débuts de la Révolution, les restrictions commandées par la situation extérieure et intérieure de la République à partir de la guerre, les vaines tentatives du Directoire pour museler la presse, et les mesures, autrement rigoureuses et efficaces, qui sont prises à partir de l'an VIII et dont, par exemple, L'Oracle, de Bruxelles et Le Troubadour, de Liège, feront les frais. 